\title{
MODEL PREDIKTIF UNTUK AKREDITASI SEKOLAH TINGKAT SEKOLAH MENENGAH PERTAMA (SMP)
}

\author{
Moh. Irvan', Yohanes Purnama ${ }^{2}$, Rendika Vhalery ${ }^{3}$ \\ Pendidikan Ekonomi, FIPPS, Universitas Indraprasta PGRI Jakarta ${ }^{1}$ \\ Statistika Terapan, MIPA, IPB University ${ }^{2}$ \\ Pendidikan Ekonomi, FIPPS, Universitas Indraprasta PGRI Jakarta ${ }^{3}$ \\ Moh.irvan@unindra.ac.id ${ }^{1}$, hansjomario@gmail.com ${ }^{2}$, rendika.vhalery@unindra.ac.id
}

\begin{abstract}
Abstrak
Aspek utama yang menentukan keberhasilan suatu bangsa adalah pendidikan. Oleh sebab itu, pemerintah memutuskan untuk seluruh sekolah perlu diberikan nilai kelayakan (akreditasi). Dalam kajian ini ingin membangun satu model prediksi untuk akreditasi sekolah di tingkat SMP. Pendekatan dengan teknik mechine learning digunakan pada pemodelan ini. Beberapa algoritma yang diterapkan memiliki nilai akurasi pada rentang $76 \%$ sampai dengan $79 \%$, hal ini masih dapat ditingkatkan kembali. Namun berdasarkan nilai AUC sebesar $76 \%$ model Random Forest memiliki prediksi yang baik dibandingkan model lainnya. Karena model Random Forest mampu memprediksi kelas minoritas tipe "akreditasi A" lebih tinggi.
\end{abstract}

Kata kunci: Prediktif; Akreditasi Sekolah; Mechine Learning;

\section{PENDAHULUAN}

Dalam rangka meningkatkan kualitas pendidikan sesuai amanat UUD Nomor 20 Tahun 2003 tentang Sistem Pendidikan Nasional. Salah satunya adalah pemerintah mengeluarkan keputusan secara tegas bahwa sekolah negeri maupun swasta agar diakreditasi. Berhubungan dengan hal tersebut pemerintah membentuk satuan badan lembaga untuk menentukan nilai kelayakan satuan pendidikan yakni Badan Akreditasi Nasional Sekolah/Madrasah (BAN-S/M). Kegiatan yang dilakukan lembaga BAN-S/M adalah merumuskan kebijakan operasional, melakukan sosialisasi kebijakan dan melaksanakan akreditasi Sekolah/Madrasah.

Hasil penilaian kelayakan tersebut berupa peringkat akreditasi sekolah yang dinyatakan dalam huruf $\mathrm{A}$ (sangat baik), B (baik), C (cukup) dan tidak terakreditasi (Badan Akreditasi Nasional, 2016). Lebih lanjut, terdapat banyak satuan pendidikan di Indonesia dari tingkat sekolah dasar dan menengah. Sehingga mustahil akan dievaluasi satu persatu tiap sekolah dengan banyaknya parameter penilaian yang ada. Oleh karena itu, perlu dibangun suatu model statistik pada dataset BAN-S/M untuk meramalkan satuan pendidikan dalam hal kelayakan. Hal tersebut yang mendorong penulis untuk mengkaji pemodelan variabel-variabel akreditasi sekolah tingkat SMP. Model yang dihasilkan 
Research and Development Journal Of Education

Vol. 5 No. 2 April 2019

p-ISSN 2406-9744

e-ISSN 2657-1056

diharapkan mampu menjadi gambaran kedepannya dalam menentukan peringkat akreditasi sekolah yang belum terakreditasi.

Banyak metode statistik yang dapat digunakan untuk model prediktif, masing-masing memiliki kelebihan dan kelemahan sesuai karakteristik datanya. Salah satu metode yang populer untuk mengetahui hubungan atau pengaruh antara dua variabel atau lebih adalah regresi (Stang, 2017). Pada tahun 1822-1911 Sir Farncis Galton lah yang pertama kali mengenalkan istilah regresi. Metode tersebut banyak digunakan pada bidang ilmu. Pada beberapa kasus, ada kondisi disaat hubungan datanya tidak dapat dimodelkan dengan regresi. Lebih lanjut, kesulitan yang dihadapi ketika variabel responnya berbentuk kategori. Untuk mengatasi masalah tersebut digunakan analisis Regresi Logistik. Regresi Logistk adalah analisis statistik yang menghubungkan variabel respon bertipe kategori dengan variabel prediktor yang bertipe kategori/numerik (Azen \& Walker, 2011). Lebih lanjut permasalahan yang ada ketika peneliti dihadapi dengan data dengan dimensi yang relatif besar dan jenis variabelnya campuran, misalnya numerik dan kategorik, baik nominal dan ordinal. Beberapa solusi untuk masalah tersebut dapat dilakukan dengan mereduksi variabel, penambahan penalti pada pendugaan parameter, seleksi variabel dan teknik-teknik lain untuk memperoleh model yang terbaik. Salah satu penerapan metode-metode statistik yang dibantu dengan bantuan komputasi komputer adalah Machine Learning. Machine Learning adalah bidang ilmu yang mengembangkan algoritma komputer untuk mengkonversi data menjadi aksi yang cerdas (Faisal, 2016). Kemudian dalam aplikasinya Machine Learning membutuhkan data untuk pemodelan (training) sebelum mengerluarkan output.

Dari uraian di atas, maka tujuan dari penelitian ini adalah untuk mengkaji model-model prediktif yang tersedia pada teknik Machine Learning dengan menerapkan kombinasi antara reduksi dan standarisasi variabel bebas untuk memperoleh model prediksi dengan akurasi yang tertinggi pada kasus prediksi akreditasi sekolah tingkat SMP. 
Research and Development Journal Of Education

Vol. 5 No. 2 April 2019

\section{METODE}

\section{Data}

Dalam menganalisis kajian ini penulis menggunakan alat bantu perangkat lunak statistik yaitu R Studio. Data yang digunakan dalam penelitian ini bersumber dari data DAPODIK (data pokok pendidikan) SMP tahun 2014. Data dalam penelitian ini terdiri dari variabel respon (tipe kategorik) dan variabel prediktor (tipe numerik/kategorik). Lebih lanjut jumlah amatannya pada data ini sebesar 20.679 instance.

1. Data respon pada penelitian ini adalah akreditasi sekolah yang terbagi menjadi dua kategori:
a. SMP yang berakreditasi A
b. SMP yang berakreditasi selain A

2. Data prediktor pada penelitian ini terdiri dari 33 variabel pengukuran yang dibangun dari instrument akreditasi.

a. Standar Kompetensi Lulusan

1) Jumlah Siswa Mengulang

2) Jumlah Siswa Putus Sekolah

b. Komponen Standar Pendidik dan Tenaga Kependidikan

3) Jumlah Guru Agama

4) Jumlah Guru Pendidikan Jasmani dan Olahraga

5) Jumlah Guru Seni Budaya

6) Jumlah Guru Teknologi Informasi dan Komunikasi

7) Jumlah Guru Matematika

8) Jumlah Guru Fisika

9) Jumlah Guru Biologi

10) Jumlah Guru Bahasa Inggris

11) Jumlah Guru IPS

12) Jumlah Guru PPKN

13) Jumlah Guru BP/BK

14) Jumlah Guru PNS

15) Jumlah Guru PNS Diperbantukan

16) Jumlah Guru PNS Departemen Agama

17) Jumlah Guru Bantu Pusat 
Research and Development Journal Of Education

Vol. 5 No. 2 April 2019

18) Jumlah Guru Honor Sekolah

19) Jumlah Guru DTY PTY

20) Jumlah Guru GTT PTT Provinsi

21) Jumlah Guru GTT PTT Kabupaten Kota

c. Komponen Standar Sarana dan Prasarana

22) Ketersediaan Listrik

23) Ketersediaan Akses Internet

24) Ketersediaan Air Sanitasi

25) Jumlah WC

26) Jumlah Ruang Kelas

27) Jumlah Siswa

28) Jumlah Ruang Guru

29) Jumlah Ruang Kepala Sekolah

30) Jumlah Ruang Tata Usaha

31) Jumlah Ruang Perpustakaan

32) Jumlah Ruang Laboratorium IPA

33) Jumlah Rombongan Belajar

\section{Metodologi}

Secara umum metodologi yang digunakan pada penelitian ini adalah:

1. Melakukan eksplorasi data.

Eksplorasi data yang dilakukan mencakup melihat pola sebaran tiap-tiap peubah bebas terhadap peubah target, memeriksa kondisi anomali pada data, melihat proporsi peubah target dan melihat deskripsi dari tiap-tiap peubah bebas.

2. Data Pre-prosesing

a. Tahapan ini melakukan pemilihan jenis tipe skala data berdasarkan karakter data dan permasalahan

b. Membagi data menjadi dua bagian, yaitu data training untuk pemodelan dan data testing untuk prediksi.

c. Menerapkan metode undersampling pada data training untuk mengatasi ketidakseimbangan kelas.

3. Memilih kandidat algoritma Machine Learning seperti Regresi Logistik, Bagging, Naïve Bayes, dan Random Forest pada data hasil undersampling. 
Research and Development Journal Of Education

Vol. 5 No. 2 April 2019

p-ISSN 2406-9744

e-ISSN 2657-1056

4. Melakukan prediksi masing-masing model algoritma Machine Learning pada data testing.

5. Evaluasi performa masing-masing model klasifikasi berdasarkan nilai konfusi matrik.

\section{HASIL DAN PEMBAHASAN}

\section{Eksplorasi Data}

Berdasarkan hasil eksplorasi data diperoleh informasi bahwa sebaran peubah target dari data tidak seimbang. Proporsi sekolah yang berakreditasi A sebanyak 67 $\%$, sedangkan proporsi sekolah yang berakreditasi selain A sebanyak $33 \%$. Berikut ini adalah visualisasi sebaran peubah target.

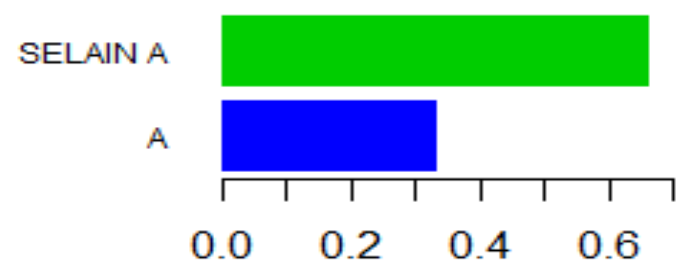

Gambar 1 Proporsi peubah target

Dari Gambar 2 terlihat bahwa sekolah yang memiliki jumlah guru PNS antara 0-10 orang cenderung berakreditasi selain $\mathrm{A}$, sedangkan untuk sekolah yang memiliki jumlah guru PNS lebih dari 10 orang cenderung berakreditasi A. Prediktor ini tergolong cukup baik untuk memprediksi status akreditasi. Berbeda halnya dengan Gambar 3, bahwasannya agak susah untuk mencari pemisah yang cocok yang membedakan sekolah yang berakreditasi A dan selain A. Hal ini tergambar dari hasil grafik sebaran peluang dari jumlah siswa antara sekolah yang berakreditasi A dan selain A yang hampir tumpang tindih.

Informasi lain yang diperoleh adalah bahwa jumlah prediktor dari data aslinya adalah sebanyak 33 prediktor dengan rincian 4 peubah kategorik dan 29 peubah kontinu. Secara umum, tidak ditemukan data yang hilang pada masing-masing prediktor. 
Research and Development Journal Of Education

Vol. 5 No. 2 April 2019

p-ISSN 2406-9744

e-ISSN 2657-1056

\section{Preposesing Data}

Dalam tahapan preposesing dilakukan partisi data secara acak menjadi dua bagian gugus data. Data yang dipartisi memiliki komposisi masing-masing 75\% untuk data training dan $25 \%$ untuk data testing. Selanjutnya data training terlebih dahulu ditreatment untuk penyeimbangan kelas dengan metode undersampling. Proporsi peubah target setelah dilakukan undersampling, adalaha sebesar 50\%.

Selanjutnya untuk memperoleh model prediksi yang baik, maka peneliti melakukan seleksi variabel. Kegiatan seleksi variabel bertujuan untuk memilih variabel-variabel prediktor yang berpengaruh signifikan terhadap variabel target. Teknik seleksi variabel yang digunakan adalah metode Regresi Logistik.

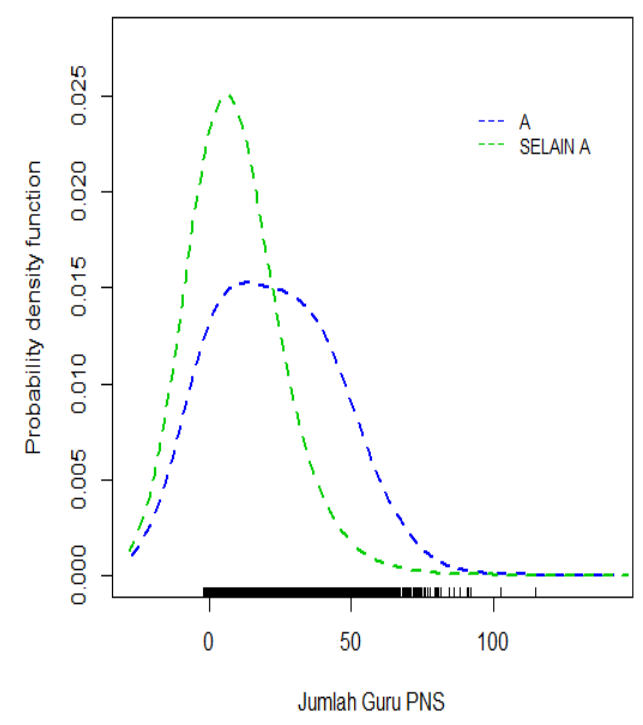

Gambar 2 Sebaran peubah jumlah guru PNS terhadap peubah target

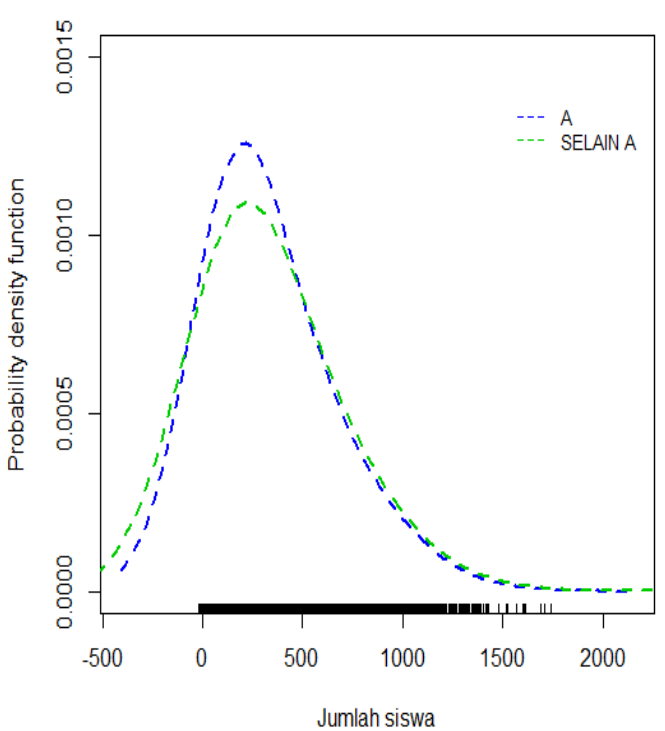

Gambar 3 Sebaran peubah jumlah siswa terhadap peubah target

\section{Model}

Pada tahapan ini akan dibangun model untuk membedakan kelompok data yang digunakan untuk prediksi kelas dengan menggunakan data training. Maka akan dicobakan beberapa algoritma yang digunakan untuk masalah prediksi tipe klasifikasi. Namun sebelumnya mesti menginstall package yang dibutuhkan oleh masing-masing algoritma klasifikasi. Beberapa algoritma yang digunakan adalah Regresi Logistik, Bagging, Naïve Bayes dan Random Forest. 
Research and Development Journal Of Education

Vol. 5 No. 2 April 2019

p-ISSN 2406-9744

e-ISSN 2657-1056

\section{Prediksi data testing dan performa akurasi model}

Setelah diperoleh model dari masing-masing algoritma klasifikasi, selanjutnya akan dilakukan prediksi menggunakan data testing. Ukuran kebaikan model yang digunakan untuk mengevaluasi hasil prediksi adalah nilai akurasi, sensitivitas dan spesifisitas. Model yang paling baik adalah model yang menghasilkan nilai tertinggi pada 3 indikator tersebut dengan nilai maksimum sebesar $100 \%$.

Di bawah ini adalah Confussion Matrix dari masing-masing algoritma.

Regresi Logistik

\begin{tabular}{ccc}
\hline $\mathrm{N}=4136$ & Aktual akreditasi selain A & Aktual akreditasi A \\
\hline Prediksi akreditasi selain A & 2272 & 378 \\
Prediksi akreditasi A & 513 & 973 \\
\hline
\end{tabular}

Bagging

\begin{tabular}{lll}
\hline $\mathrm{N}=4136$ & Aktual akreditasi selain A & Aktual akreditasi A \\
\hline Prediksi akreditasi selain A & 2141 & 340 \\
Prediksi akreditasi A & 644 & 1011 \\
\hline
\end{tabular}

Naïve Bayes

\begin{tabular}{lll}
\hline $\mathrm{N}=4136$ & Aktual akreditasi selain A & Aktual akreditasi A \\
\hline Prediksi akreditasi selain A & 2381 & 548 \\
Prediksi akreditasi A & 404 & 803 \\
\hline
\end{tabular}

Random Forest

\begin{tabular}{lll}
\hline N=4136 & Aktual akreditasi selain A & Aktual akreditasi A \\
\hline Prediksi akreditasi selain A & 2215 & 311 \\
Prediksi akreditasi A & 570 & 1040 \\
\hline
\end{tabular}

Dari nilai konfusi matrik, maka dapat dihitung nilai-nilaiyang dapat dijadikan evaluasi kinerja klasifikasi. Berikut ini disajikan nilai akurasi, sensitivitas, spesifisitas, dan $A U C$ dari masing-masing model yang diperoleh. 
Research and Development Journal Of Education

Vol. 5 No. 2 April 2019

Tabel Evaluasi model

\begin{tabular}{lllll}
\hline Model & Akurasi & Sensitivitas & Spesifisitas & AUC \\
\hline Regresi Logistik & $78,45 \%$ & $72,02 \%$ & $81,58 \%$ & $75,60 \%$ \\
Bagging & $76,21 \%$ & $74,83 \%$ & $76,88 \%$ & $73,90 \%$ \\
Naïve Bayes & $76,98 \%$ & $85,49 \%$ & $59,44 \%$ & $73,91 \%$ \\
Random Forest & $78.69 \%$ & $79,53 \%$ & $76,98 \%$ & $76,14 \%$ \\
\hline
\end{tabular}

Berdasarkan tabel evaluasi model di atas, maka dapat disimpulkan bahwa algoritma Random Forest memiliki performa yang lebih baik daripada algoritma lainnya. Hal ini ditunjukkan oleh nilai akurasi, sensitivitas, spesivisittas dan AUC yang paling tinggi daripada algoritma lainnya. Artinya bahwa, algoritma Random Forest lebih baik dalam memprediksi kelas minoritas (akreditas A) dan kelas mayoritas (akreditasi selain A). Namun demikian, performa model Regresi Logistik cukup bersaing dengan algoritma Random Forest.

\section{SIMPULAN}

Dari uraian di atas dapat disimpulkan bahwa model Random Forest mampu menghasilkan tingkat prediksi yang lebih baik daripada 3 model lainnya. Namun, perlu digaris bawahi bahwa, hasil akurasi ini tidak serta-merta memberikan redaksi bahwa model Random Forest merupakan model yang lebih baik daripada modelmodel lain dalam semua kasus pemodelan klasifikasi. Model Random Forest hanya merupakan model terbaik untuk kasus ini dengan kondisi data dan variabel yang peneliti gunakan. Selanjutnya model yang diperoleh masih belum optimal untuk memprediksi kelas akreditasi sekolah, karena masih terdapat variabel prediktor yang belum masuk dalam model dan perlu dikaji lebih lanjut. Karena masih banyak perlakuan yang belum dilakukan oleh peneliti, perlakuan ini tentunya untuk menghasilkan nilai akurasi yang setinggi mungkin tanpa mengabaikan sensitivitas dan spesifisitasnya. 
Research and Development Journal Of Education

Vol. 5 No. 2 April 2019

p-ISSN 2406-9744

e-ISSN 2657-1056

\section{DAFTAR PUSTAKA}

Alpaydın, E. (2010). Introduction to Machine Learning (Second ed.). Cambridge, London: The MIT Press.

Badan Akreditasi Nasional. (2016). Pedoman Akreditasi Sekolah/Madrasah Tahun 2016. Jakarta: Badan Akreditasi Nasional Sekolah/Madrasah.

Gayatri, N., Nickolas, S., Reddy, A., \& Chitra, R. (2009). Performance Analysis Of Data Mining Algorithms for Software Quality Prediction. International Conference on Advances in Recent Technologies in Communication and Computing, Hlm. 393-395.

He, H., \& Garcia, E. A. (2009). Learning from Imbalanced Data. IEEE Transactions on Knowledge and Data Engineering, Vol. II. No. 9, Hlm. 1263-1284.

Korb, K. B., \& Nicholson, A. E. (2011). Bayesian Artificial Intelligence (2nd ed.). Florida: CRC Press.

Faisal, M. R. (2016). Data Science, Klasifikasi dengan Bahasa Pemprograman R. Indonesia net dev community: Banjarmasin.

Stang. (2017). Aplikasi Statistik Multivariat Dalam Penelitian Kesehatan. Jakarta: Mitra Wacana Media.

Azen, R \& Walker, C. M. (2011). Categorical Data Analysis for the Behavoral and Social Sciences. New York: Taylor and Francis Group. 